\title{
SEASONAL DYNAMICS OF AGRICULTURAL SOIL COVER IN RUNOFF GENERATION
}

\author{
Wagner de Aguiar ${ }^{1}$, Silvio C. Sampaio ${ }^{2 *}$, Julio C. Paisani ${ }^{3}$, Marcelo B. Remor ${ }^{2}$, Ralpho R. dos Reis ${ }^{2}$ \\ $2^{2}$ Corresponding author. Universidade Estadual do Oeste do Paraná/ Cascavel - PR, Brasil. \\ E-mail: silvio.sampaio@unioeste.br | ORCID ID: https://orcid.org/0000-0002-9034-432X
}

\section{KEYWORDS}

flood, flow peak, hydrological simulation, agricultural soil use.

\begin{abstract}
Seasonal changes in agricultural soil use due to agroclimatic conditions affect the water cycle in watersheds. This study aimed to understand the temporal variation of runoff inherent to the seasonal occupation dynamics of the agricultural soil in the basin that drains the upper valley of the Marrecas River, upstream of the urban perimeter of Francisco Beltrão, PR. The effects of runoff were verified through flow peaks simulated by the HEC-HMS model in twelve monthly soil use scenarios, under seven precipitation return periods. The results indicated a strong relationship between bare soil and flow peaks, temporally delimiting April and March as the largest runoff generators and January and August as the smallest ones. The ratio quantified by rates of increase in flow peaks ranging from 0.78 to $1.64 \mathrm{~m}^{3} \mathrm{~s}^{-1}$ per $\mathrm{km}^{2}$ of bare soil. In addition, the survey of historical precipitation data also warns of the generation of large runoff volumes in October. Therefore, the strong correlation between the increase in flow peaks and occupation by bare soil can be quantified with good precision, but it is also necessary to consider historical precipitation records to understand the temporal distribution of runoff and flood risks.
\end{abstract}

\section{INTRODUCTION}

The hydrographic region of the Marrecas River upstream of the urban perimeter of Francisco Beltrão, Paraná, which is used as a source of public supply for that city, has more than $65 \%$ of its area occupied by agricultural activities. This region was colonized by immigrants from the states of Santa Catarina and Rio Grande do Sul, in higher proportions from the 1940s (Cassol \& Morais, 2014), who occupied small plots of land characterizing a way of family agricultural production (Savoldi \& Cunha, 2010). This occupation model led to profound changes in the landscape, with the replacement of the Mixed Ombrophilous Forest by agricultural use (Cassol \& Morais, 2014).

Removal of forests reduces rain interception and plant transpiration, increasing runoff (Githui et al., 2009). Agricultural cultivation, one of the primary forest substitutes, can further increase runoff generation by compacting soil horizons, increasing soil density, and reducing the infiltration rates (Ankeny et al., 1990; AbuHamdeh, 2003).

Soil type, topography, and soil cover are the most important factors in controlling the runoff generation process. Soil cover is considered a dynamic element in runoff formation, as soil type and topography have insignificant short-term changes (Miller et al., 2002).

Changes in land use and occupation directly reflect the degree of human influence, which in turn affects the hydrological cycle and availability of water resources (Lin et al., 2014). Soil cover varies due to the stages of development of annual crops and the off-season, which occur seasonally and depend on social, economic, and environmental factors (Zhao et al., 2014; Tesemma et al., 2015; You, 2017). Changes in land use conditioned by seasonal climate changes alter the balance between runoff and water infiltration (Tucci \& Clarke, 1997).

Changes in soil cover have been addressed in several studies on the effects of urbanization (Suriya \& Mudgal, 2012; Zope et al., 2016; Niemi et al., 2017), evolution of anthropogenic occupation in watersheds (Fang et al., 2012; Sanyal et al., 2014; Rodriguez-Lloveras et al., 2015; Napoli et al., 2017; Welde \& Gebremariam, 2017), and influence of vegetation cover (Marques et al., 2007; Mu et al., 2015; Zhang et al., 2015; Silva et al., 2016; Yu et al., 2016) on the balance between the elements of the hydrological cycle. However, few studies have sought to investigate the effects of the seasonality of agricultural soil use on runoff

\footnotetext{
${ }^{1}$ Universidade Tecnológica Federal do Paraná/ Francisco Beltrão - PR, Brasil.

${ }^{3}$ Universidade Estadual do Oeste do Paraná/ Francisco Beltrão - PR, Brasil.

Received in: 8-7-2017

Accepted in: 9-6-2019
} 
generation over a hydrological year.

Given this context and considering the recurrent flooding in the urban perimeter of Francisco Beltrão, PR, Brazil, which may have as one of the primary motivators the agricultural activities developed in the drainage basin, this study aimed to understand the hydrological behavior of seasonal changes in agricultural soil cover in the basin that drains the upper valley of the Marrecas River under twelve soil use scenarios representative of each month of the year in response to the runoff response on flow peaks, aiming at the knowledge of the temporal distribution of runoff and flood risks.

\section{MATERIAL AND METHODS}

The study was carried out in the Marrecas River basin, upstream of the urban perimeter of Francisco Beltrão, Paraná, Brazil, at the control point with geographical coordinates $26^{\circ} 04^{\prime} 53^{\prime \prime} \mathrm{S}$ and $53^{\circ} 04^{\prime} 30^{\prime \prime} \mathrm{W}$. The basin has an average altitude of $736 \mathrm{~m}$ and extends through three municipalities of Paraná (Marmeleiro, Flor da Serra do Sul, and Francisco Beltrão) (Figure 1).

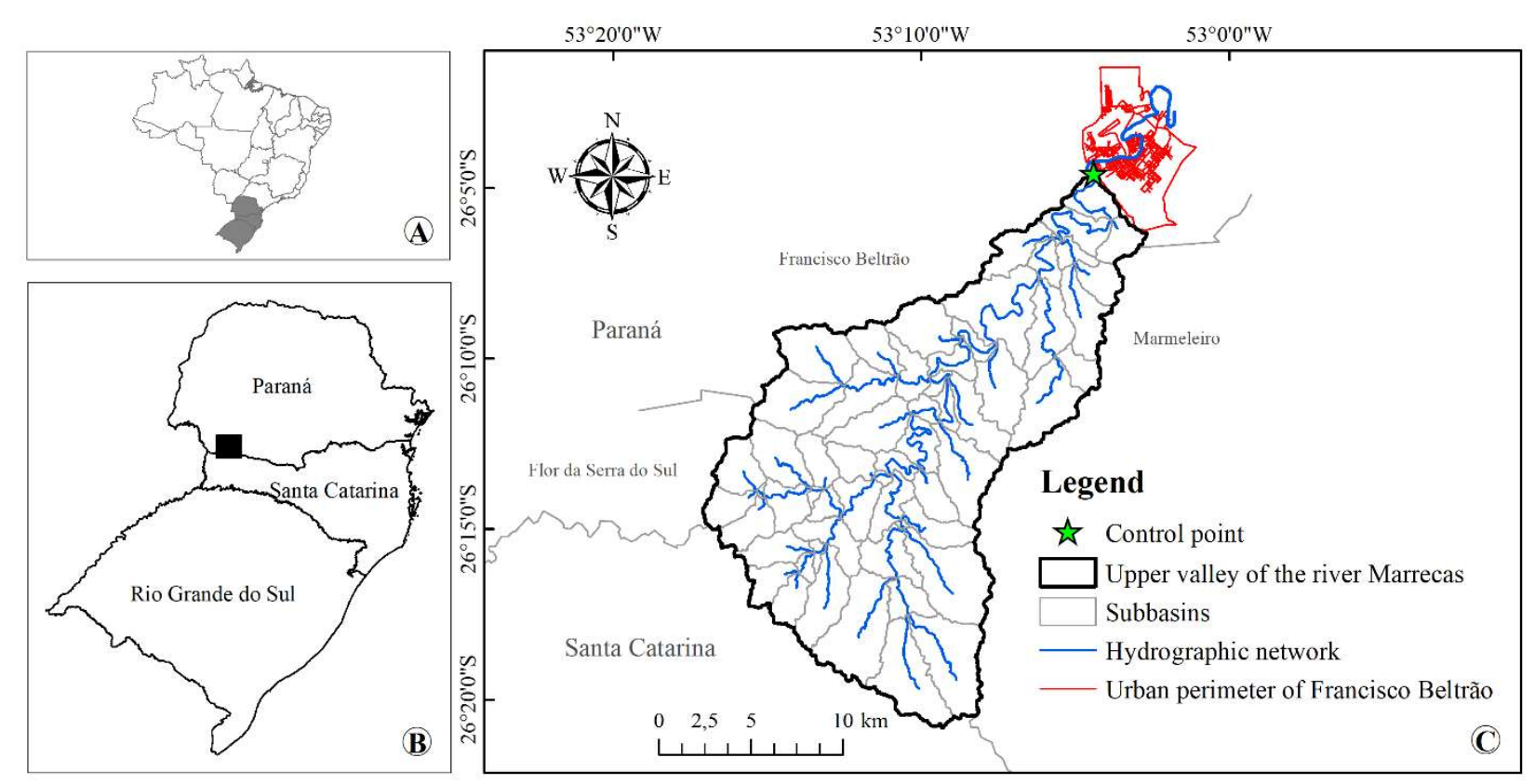

FIGURE 1. Spatial distribution of the South region of Brazil (A), location of Marrecas River basin (B), and Marrecas River basin object of this study (C).

Hydrological simulations included the parameter peak flow, which is the runoff response in the drainage channel, whose overflow to its banks determines the moment of maximum flood occupation. The simulations were performed by the model HEC-HMS 4.1 (Scharffernberg, 2013), which required the use of physical characteristics of the basin and channels in the model, with information on the slope, runoff coefficient, roughness, delay time, among others. The precipitation data and control specifications with respective ranges to obtain responses.

The characteristics of the basin and channels were obtained using the extension HEC-GeoHMS (Geospatial Hydrologic Modeling), executed by the program ArcMap 10.1. HEC-GeoHMS requires the input of a digital elevation model (DEM) and drainage channel information, providing data of runoff and flood wave propagation in the channels.

The DEM, with a spatial resolution of $30 \mathrm{~m}$, was readjusted to the Marrecas River hydrographic network using more accurate charts from the Army, aiming at delineating the Marrecas River basin, upstream of the urban perimeter of Francisco Beltrão, PR, with $337.88 \mathrm{~km}^{2}$. To represent better the dynamics of the hydrological processes, the basin was subdivided into 59 subbasins, whose flows in the channels are integrated to compose the total basin flow by flood wave propagation estimates. The subbasin subdivision criteria are determined by the watercourses generated from minimum drainage areas of $1 \%$ of the total area and the boundaries of each subbasin delineated from contribution surfaces of each junction point of two hydrographic lines, whose distribution can be observed in Figure 1.

The methods adopted for peak flow simulations by the HEC-HMS model were pre-selected in the HECGeoHMS, chosen based on the availability of information about drainage channels and the basin: infiltration losses (SCS curve number method), transformation of effective precipitation into runoff (SCS unit hydrograph method), and wave propagation in the channel (Muskingum-Cunge method).

Soil use was classified by the software Spring, with images from the Landsat 8 satellite OLI sensor, generated by the U.S. Geological Survey (USGS), and CBERS 4 MUX sensor, generated by the National Institute for Space Research (INPE). These images were segmented with similarity level 10 and a minimum area of 20 pixels. Uses were individualized by the Bhattacharya classifier to an acceptance threshold of $99.9 \%$. The composition of uses took into consideration the classification key shape, color, and texture that can be identified in the images.

Twelve scenarios, one for each month of the year, were generated in order to verify the seasonal influence on the use and occupation of agricultural soil on runoff, as characteristic bases of the basin for the hydrological simulations of flow peaks, representing the uses practiced seasonally in the study area, corresponding to images dated: 01/13/2017, 02/28/2017, 03/13/2016, 04/01/2017, 
05/24/2017, 06/15/2015, 07/03/2016, 08/04/2016, 09/21/2016, 10/07/2016, 11/24/2016, and 12/05/2014.

Seasonal soil use in the Marrecas River basin is dynamic over the year, mainly in agricultural areas, as well as its effects on the water cycle (Tucci \& Clarke, 1997; AbuHamdeh, 2003; Esch et al., 2014). Thus, regions occupied by forests, pastures, and water bodies had their areas fixed based on mean values obtained in classifications for all scenarios. This factor allowed the verification of variations in the occupation of agricultural areas, with the possibility of recognition by the classifier as bare soil, initial stage crops, and intermediate and final stage crops, as well as their impacts on runoff generation.

The twelve soil use scenarios were reclassified into $\mathrm{CN}$ (curve number) quantities according to the recommended by the Soil Conservation Service of the U.S. Department of Agriculture (USDA-SCS), generated by HEC-GeoHMS. For this, soil uses were compared with hydrological groups of soils in the basin under the antecedent moisture condition (AMC) II (USDA, 1986).

Flood wave propagation calculated by the Muskingum-Cunge method required information on width, lateral slope, and Manning roughness (n) of drainage channels. These data were collected in the field by threepoint sampling for each channel of the 59 subbasins, totaling 177 sampled points.

Precipitations were generated by intensity-durationfrequency curves proposed by Fendrich (2011) for Francisco Beltrão, PR, for return periods of 2, 5, 10, 25, 50, 100 , and 200 years. Duration of each precipitation corresponded to the concentration time of the basin under study, calculated by the formula US Corps of Engineers
(Silveira, 2005) and distributed by the alternate block method, with 15-min intervals.

Simulation control specifications were determined to obtain full details of basin responses on flow distribution. For this, 30 hours were totaled from the beginning to the end of the process for the simulations of each treatment.

The results comprised a randomized block design with twelve treatments representative of the monthly scenarios of agricultural soil occupation. In order to understand the variations in flow peaks (response variable) in the monthly scenarios under different conditions of the probability of precipitation, treatments were analyzed in seven blocks/replications formed by return periods of 2,5 , $10,25,50,100$, and 200 years. The results were verified by analysis of variance (ANOVA) at 5\% significance. Multiple verifications of peak flow means, generated in each soil use scenario, were analyzed two by two by the Tukey test at 5\% significance when the null hypothesis $\left(\mathrm{H}_{\mathrm{o}}\right)$ was rejected.

\section{RESULTS AND DISCUSSION}

The twelve-month scenarios showed significant variations in the use of agricultural areas over the representative year (Figure 2). Bare soils had a higher occurrence in April, with $124.1 \mathrm{~km}^{2}$, due to the off-season, and lower occurrence in August, with $4.7 \mathrm{~km}^{2}$, already occupied mainly by corn and soybean plantations. Occupation with initial stage crops had the largest area in May, with $175.14 \mathrm{~km}^{2}$, and the lowest area in April, with $82.45 \mathrm{~km}^{2}$. Intermediate and final stage crops presented the highest occupation in January, with $70.77 \mathrm{~km}^{2}$, while the lowest occupation was observed in March, with $12.45 \mathrm{~km}^{2}$, due to the beginning of crop harvesting periods.

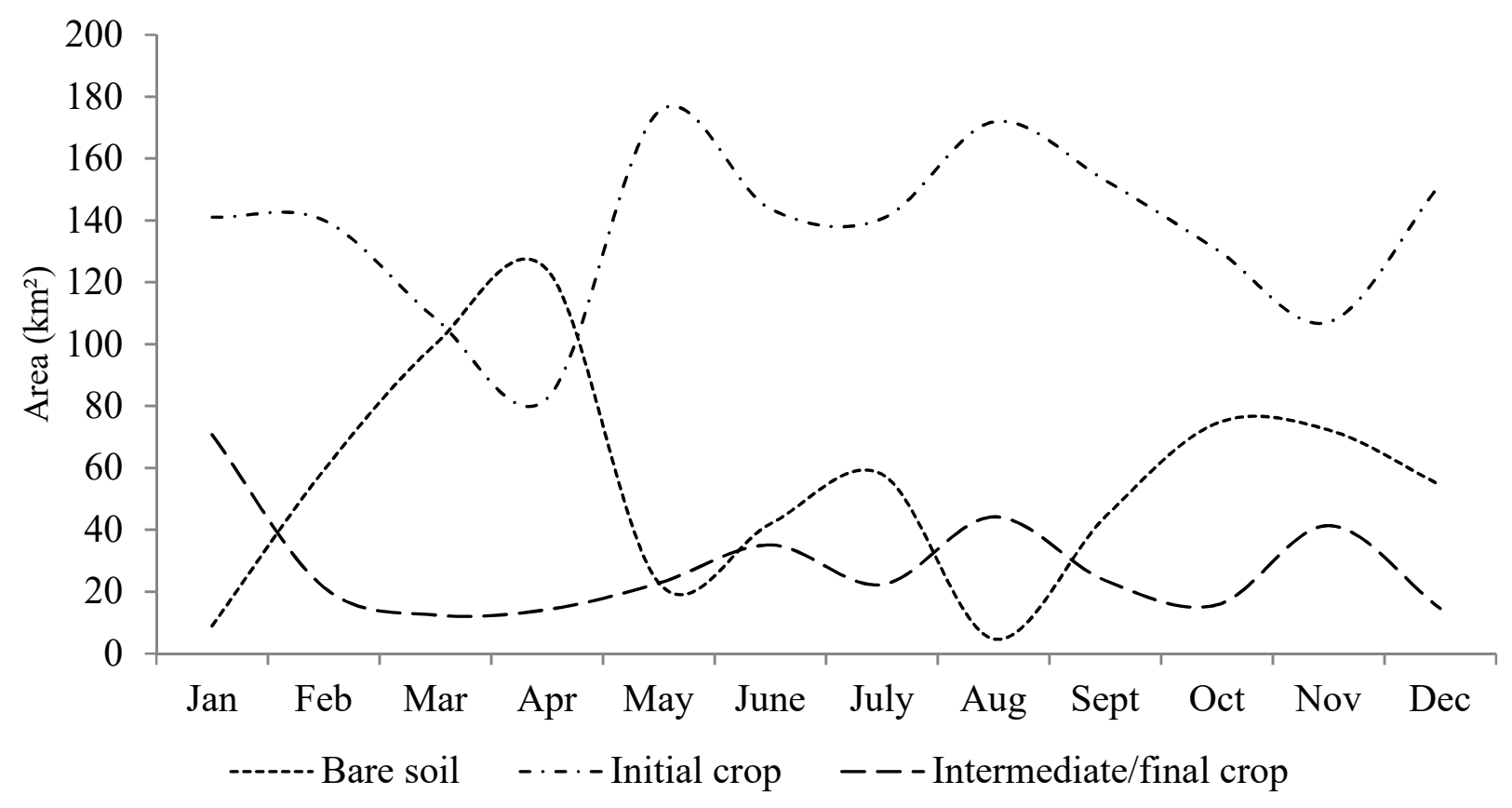

FIGURE 2. Variations in agricultural soil use in the Marrecas River basin in a study over one year. 
The classification of higher amounts of areas occupied by initial stage crops (Figure 2) may be related to the spectral similarity of this use to areas occupied by postharvest sprouting or even weeds. Spectral similarities were due to the phenological stages of vegetation, with the greater or lesser difficulty of separation, also depending on the quality of spatial resolution of images (Ponzoni \& Rezende, 2002; Esch et al., 2014).

Seasonal changes in agricultural soil use due to seasonal climate variations cause significant changes in the water cycle (Tucci \& Clarke, 1997). Soil exposure in the tillage for planting and the different development stages of annual crops can change the dynamics of runoff over the year and, consequently, peak flows (Zhao et al., 2014; Sanyal et al., 2014, Napoli et al., 2017).

Peak flows generated in the monthly soil use scenarios (treatments) in each precipitation return period (block/replication) are shown in Table 1. The null hypothesis of the ANOVA test at 5\% significance was rejected, and the Tukey test at 5\% significance level was carried out.

TABLE 1. Flow peaks generated for each treatment.

\begin{tabular}{|c|c|c|c|c|c|c|c|}
\hline \multirow{3}{*}{ Treatment (month) } & \multicolumn{7}{|c|}{ Peak flow $\left(\mathrm{m}^{3} \mathrm{~s}^{-1}\right)$} \\
\hline & \multicolumn{7}{|c|}{ Precipitation return period (years) } \\
\hline & 2 & 5 & 10 & 25 & 50 & 100 & 200 \\
\hline January ${ }^{\mathrm{g}^{*}}$ & 499.1 & 719.3 & 931.8 & $1,294.6$ & $1,644.8$ & $2,059.6$ & $2,542.4$ \\
\hline Februaryde & 548.7 & 777.7 & $1,004.2$ & $1,369.8$ & $1,733.2$ & $2,159.5$ & $2,643.7$ \\
\hline $\operatorname{March}^{\mathrm{b}}$ & 578.3 & 816.0 & 1044 & $1,417.0$ & $1,785.8$ & $2,214.7$ & $2,714.0$ \\
\hline April $^{\mathrm{a}}$ & 596.5 & 831.3 & $1,068.3$ & $1,447.1$ & $1,817.0$ & $2,248.4$ & $2,748.5$ \\
\hline May $^{f}$ & 526.0 & 751.5 & 973.3 & $1,333.9$ & $1,689.7$ & $2,111.7$ & $2,600.2$ \\
\hline June $^{f}$ & 531.7 & 758.9 & 979.8 & $1,346.2$ & $1,704.3$ & $2,127.0$ & $2,614.2$ \\
\hline July ${ }^{\text {cde }}$ & 548.8 & 779.3 & $1,005.2$ & $1,371.3$ & $1,737.2$ & $2,161.4$ & $2,645.1$ \\
\hline August ${ }^{\mathrm{g}}$ & 505.8 & 726.6 & 941.0 & $1,306.6$ & $1,657.6$ & $2,074.7$ & $2,564.2$ \\
\hline Septemberef & 537.8 & 766.3 & 987.5 & $1,355.7$ & $1,717.0$ & $2,138.3$ & $2,625.3$ \\
\hline October ${ }^{\mathrm{c}}$ & 562.1 & 792.4 & $1,019.6$ & $1,391.6$ & $1,758.7$ & $2,186.4$ & $2,677.2$ \\
\hline November & 554.2 & 785.5 & $1,009.9$ & $1,379.5$ & $1,745.5$ & $2,170.4$ & $2,661.6$ \\
\hline December ${ }^{\text {cde }}$ & 549.3 & 779.2 & $1,005.4$ & $1,371.3$ & $1,737.3$ & $2,159.1$ & $2,645.0$ \\
\hline
\end{tabular}

*Equal letters represent statistical equality between peak flows generated by monthly scenarios analyzed two by two by the Tukey test at $5 \%$ significance.

April presented the highest flow peaks, followed by March, which is due to the largest areas occupied by bare soil, while the lowest flow peaks were observed in January and August, occupied by the smallest areas of bare soil (Figure 2). This relationship between soil use and runoff generation allowed the application of linear regression statistical methods for the establishment of increase rates in peak flows as a function of bare soil area. This statistical verification demonstrated that the increase rates in peak flows depend on the intensity of precipitation to which the soil use scenario is subjected, expressed by the proposed return periods (Figure 3). 

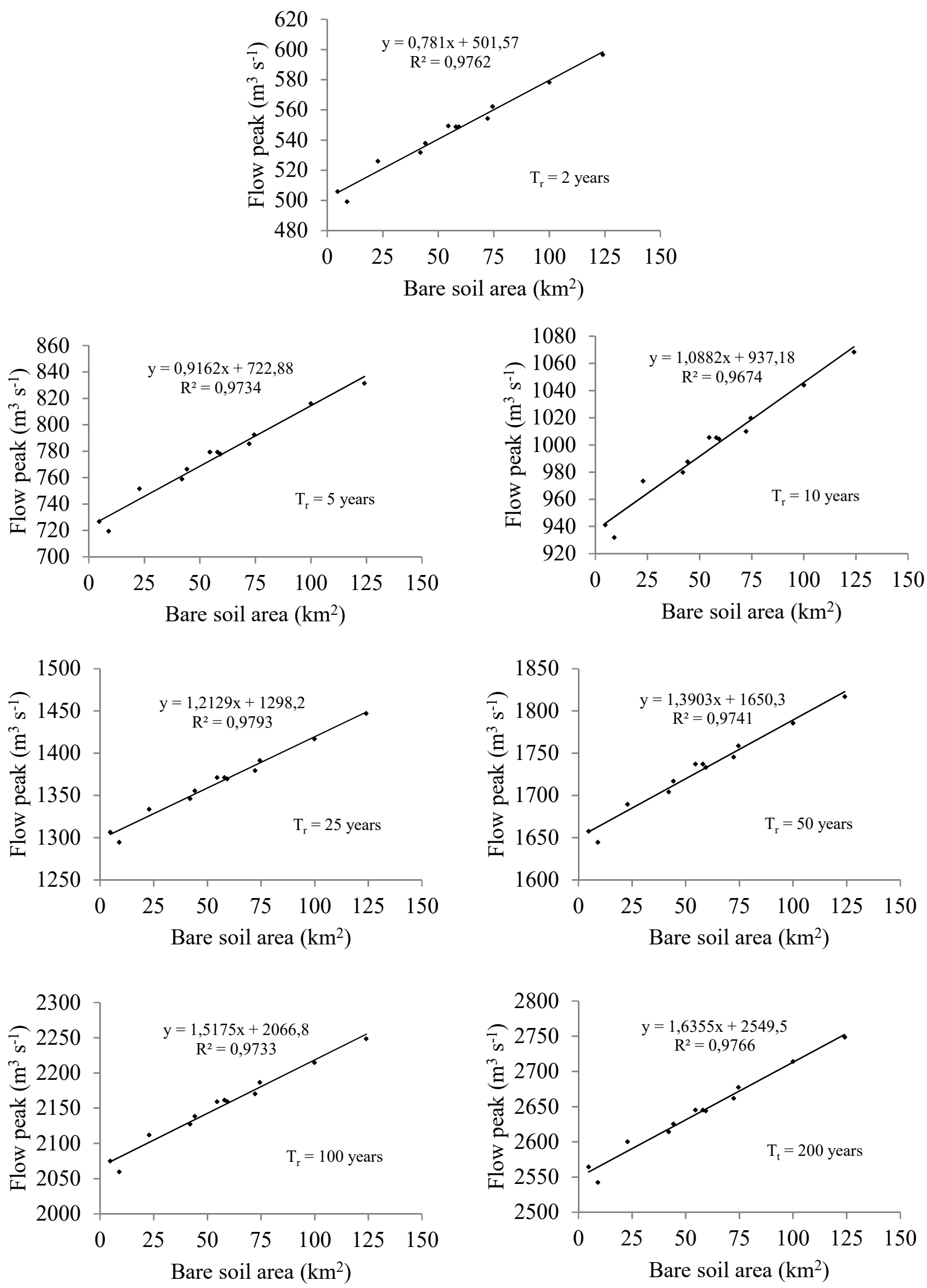

FIGURE 3. Linear regressions of flow peaks as a function of bare soil areas for each projected precipitation return period (Tr). 
The analysis of the angular coefficients of the straight lines (Figure 3) allows quantifying the increase rates in peak flows as a function of bare soil area, which ranged from 0.78 to $1.64 \mathrm{~m}^{3} \mathrm{~s}^{-1}$ for return periods of 2 and 200 years, respectively, for each $\mathrm{km}^{2}$ of bare soil. Linear regressions showed a high positive linear correlation $\left(\mathrm{R}^{2}\right)$, allowing obtaining the increase rates in peak flows as a function of bare soil area with good precision for other return periods, i.e., varying probabilities of extreme precipitation.

In contrast to the soil exposed in the months with higher soil cover, occupied by intermediate and final tillage, January and August, were also the seasons with greater retention of runoff. Corroborating with the results, the month with the lowest occupation by intermediate and final crops, March presented the second position of the highest flow peaks. Occupation of crops at an early stage showed secondary importance in the variations of the flow peaks.

Soil exposure interrupts evapotranspiration, caused by evaporation of water intercepted in the leaves and physiological transpiration of plants, increasing runoff and soil loss (Zhang et al., 2015; Eum et al., 2016; Silva et al., 2016) when compared to soils occupied by pasture and seasonal crops (Zhao et al., 2014). Intermediate and final stage crops have high evapotranspiration rates and water demand (Mu et al., 2015; Gondim et al., 2017), as well as higher hydraulic conductivities, proportional to the diameter and length of roots ( $\mathrm{Yu}$ et al, 2016), increasing water infiltration, slowing runoff, and reducing flow peaks (Sanyal et al., 2014; Tesemma et al., 2015; Napoli et al., 2017).

April and March presented the highest runoff generation potential, temporally demarcating a time of the year of greater attention to potential flood events regarding soil use in the contributing basin. However, these two months have mean precipitation (Figure 3) below the average of all months, but extreme precipitation events are increasing both in magnitude and frequency and may be related to global climate change (Wang et al., 2013; Du et al., 2014).

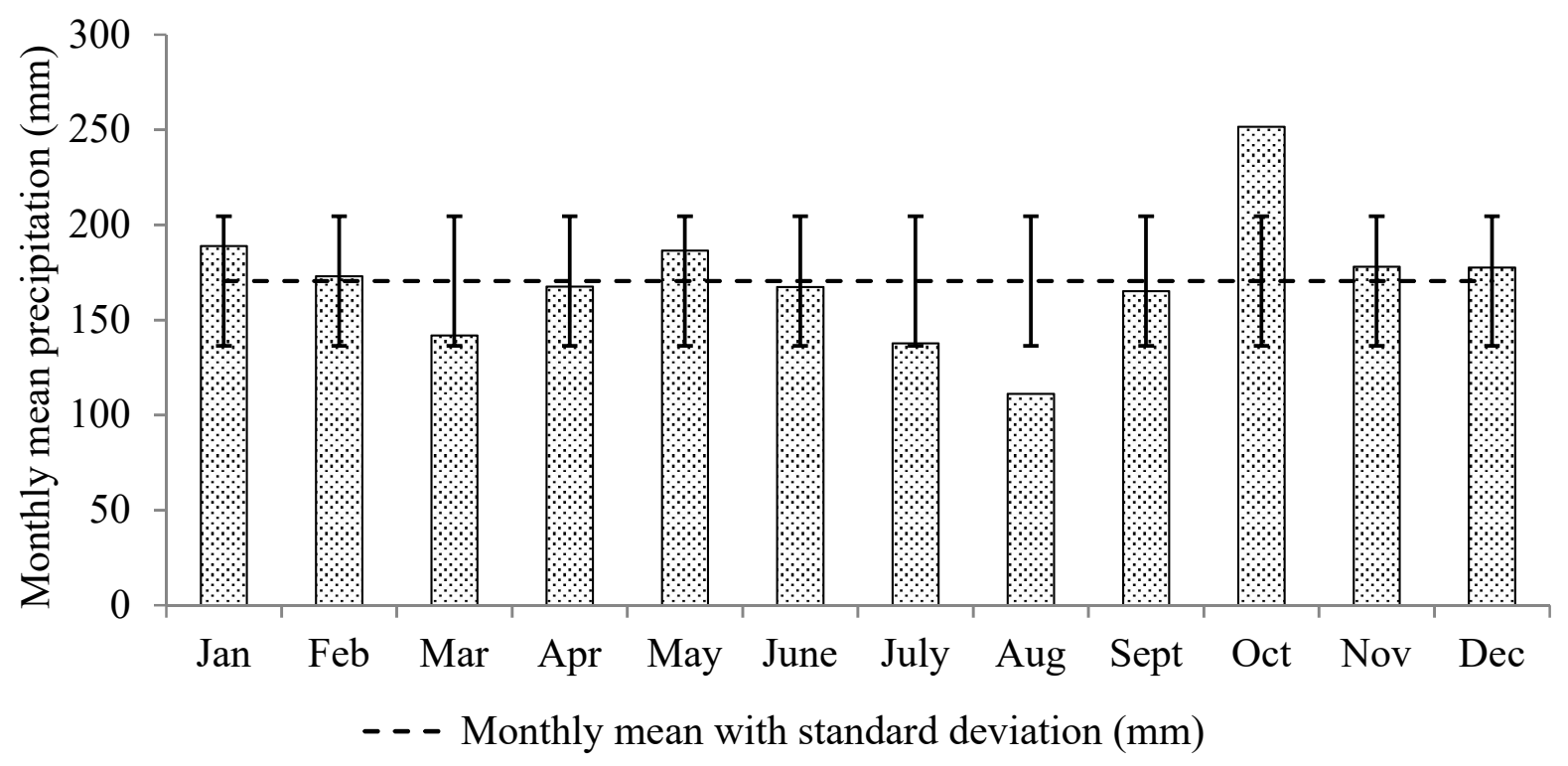

FIGURE 4. Monthly mean precipitation from 1974 to 2016 of IAPAR conventional agrometeorological station of Francisco Beltrão.

The survey of monthly mean precipitation (Figure 3) also warns for October regarding the potential of runoff generation and flood risks due to the record of the highest monthly mean precipitations of the last 43 years for this month. Statistical analysis of these historical data showed that the mean precipitation in October exceeded the maximum variation of the standard deviation of the mean precipitation for each month. Also, October has the thirdlargest peak flow, along with July, November, and December, which also need attention.

Temporal distributions, as well as runoff generation rates, can be extrapolated to neighboring basins that have similar morphoclimatic characteristics (Lopes et al., 2017), considering the lack of hydrological data in Brazil (Pontes et al., 2016). This knowledge can compose a database on long-term flows, essential for planning and managing regional water resources (Pruski et al., 2016).

\section{CONCLUSIONS}

Hydrological simulations of scenarios of the seasonal occupation of agricultural soils identified strong correlation with the increase in the runoff, with maximum values in April and March, which are considered off-season periods, whose soil exposure reaches large arable areas. In addition, the comparison of results with historical precipitation data also warns for the great potential of runoff generation due to high precipitation volumes, with maximum values in October. It shows that the temporal distribution of runoff and flood risks cannot be performed solely by seasonal agricultural soil use factors.

\section{ACKNOWLEDGMENTS}

To UTFPR-FB (Federal University of Technology Paraná, campus of Francisco Beltrão), PGEAGRI (Graduate Program in Agricultural Engineering of UNIOESTE, campus of Cascavel), Araucária Foundation, CAPES (Coordination for the Improvement of Higher Education Personnel), 3rd Independent Fire Department Subgroup of the Fire Department of Paraná, and Laboratory of Geoprocessing of UNIOESTE (campus of Francisco Beltrão) for the support in the development of this research. 


\section{REFERENCES}

Abu-Hamdeh NH (2003) Compaction and subsoiling effects on corn growth and soil bulk density. Soil Science Society of America Journal 67(4):1213-1219. DOI: http://dx.doi.org/10.2136/sssaj2003.1213

Ankeny MD, Kaspar TC, Horton R (1990)

Characterization of tillage and traffic effects on unconfined infiltration measurements. Soil Science Society of America Journal 54(3):837-840. DOI:

http://dx.doi.org/10.2136/sssaj1990.03615995005400030037x

Cassol HLG, Moraes EC (2014) Recorte municipal do sudeste e sudoeste paranaense: relação entre os fatores sociais e econômicos com o desflorestamento na Floresta Ombrófila Mista? Revista Espinhaço 3(1):43-61.

Du H, Xia J, Zeng S, She D, Liu J (2014) Variations and statistical probability characteristic analysis of extreme precipitation events under climate change in Haihe River Basin, China. Hydrological Processes 28:913-925. DOI: http://dx.doi.org/10.1002/hyp.9606

Esch T, Metz A, Marconcini M, Keil M (2014) Combined use of multi-seasonal high and medium resolution satellite imagery for parcel-related mapping of cropland and grassland. International Journal of Applied Earth Observation and Geoinformation 28:230-237. http://dx.doi.org/10.1016/j.jag.2013.12.007

Eum H-I, Dibike Y, Prowse T (2016) Comparative evaluation of the effects of climate andland-cover changes on hydrologic responses of the MuskegRiver, Alberta, Canada. Journal of Hydrology: Regional Studies 8:198221. DOI: http://dx.doi.org/10.1016/j.ejrh.2016.10.003

Fang N-F, Shi Z-H, Li L, Guo Z-L, Liu Q-J, Ai L (2012) The effects of rainfall regimes and land use changes on runoff and soil loss in a small mountainous watershed. Catena 99:1-8. DOI: http://dx.doi.org/10.1016/j.catena.2012.07.004

Fendrich R (2011) Chuvas intensas para obras de drenagem no Estado do Paraná. Curitiba, O Autor, 3 ed. ampl. 89p.

Githui F, Mutua F, Bauwens W (2009) Estimating the impacts of land-cover change on runoff using the soil and water assessment tool (SWAT): case study of Nzoia catchment, Kenya. Hydrological Sciences Journal 54(5):899-908. DOI:

http://dx.doi.org/10.1623/hysj.54.5.899

Gondim RS, Evangelista SRM, Maia AHN, Duarte AS (2017) Climate change impacts on water demand of melon plants in Jaguaribe-Apodi region, Brazil. Engenharia Agrícola 37(3):591-602. DOI:

http://dx.doi.org/10.1590/1809-4430-

Eng.Agric.v37n3p591-602/2017

Lin K, Lv F, Chen L, Singh VP, Zhang Q, Chen X (2014) Xinanjiang model combined with Curve Number to simulate the effect of land use change on environmental flow. Journal of Hydrology 519:3142-3152. DOI: http://dx.doi.org/10.1016/j.jhydrol.2014.10.049
Lopes TR, Zolin CA, Prado G, Paulino J, Almeida FT (2017) Regionalization of maximum and minimum flow in the Teles Pires basin, Brazil. Engenharia Agrícola 37(1):54-63. DOI: http://dx.doi.org/10.1590/1809-4430Eng.Agric.v37n1p54-63/2017

Marques MJ, Bienes R, Jiménez L, Pérez-Rodríguez R (2007) Effect of vegetal cover on runoff and soil erosion under light intensity events. Rainfall simulation over USLE plots. Science of the Total Environment 378:161165. DOI: http://dx.doi.org/10.1016/j.scitotenv.2007.01.043

Miller SN, Kepner WG, Mehaffey MH, Hernandez M, Miller RC, Goodrich DC, Devonald KK, Heggem DT Miller WP (2002) Integrating landscape assessment and hydrologic modeling for land cover change analysis. Journal of the American Water Resources Association 38:915-929. DOI: http://dx.doi.org/10.1111/j.17521688.2002.tb05534.x

Mu W, Yu F, Li C, Xie Y, Tian J, Liu J, Zhao N (2015) Effects of rainfall intensity and slope gradient on runoff and soil moisture content on different growing stages of spring maize. Water 7: 2990-3008. DOI: http://dx.doi.org/10.3390/w7062990

Napoli M, Massetti L, Orlandini S (2017) Hydrological response to land use and climate changes in a rural hilly basin in Italy. Catena 157:1-11. DOI: http://dx.doi.org/10.1016/j.catena.2017.05.002

Niemi TJ, Warsta L, Taka M, Hickman B, Pulkkinen S, Krebs G, Moisseev DN, Koivusalo H, Kokkonen T (2017) Applicability of open rainfall data to event-scale urban rainfall-runoff modelling. Journal of Hydrology 547:143155. DOI: http://dx.doi.org/10.1016/j.jhydrol.2017.01.056

Pontes LM, Viola MR, Silva MLN, Bispo DFA, Curi N (2016) Hydrological modeling of tributaries of Cantareira sytem, southeast Brazil, with the SWAT model.

Engenharia Agrícola 36(6):1037-1049. DOI:

http://dx.doi.org/10.1590/1809-4430-

Eng.Agric.v36n6p1037-1049/2016

Ponzoni FJ, Rezende ACP (2002) Influência da resolução espacial de imagens orbitais na identificação de elementos da paisagem em Altamira-PA. Revista Árvore 26(4):403-410.

Pruski FF, Rodriguez RDG, Pruski PL, Nunes AA, Rego FS (2016) Extrapolation of regionalization equations for long-term averare flow. Engenharia Agrícola 36(5):830838. DOI: http://dx.doi.org/10.1590/1809-4430Eng.Agric.v36n5p830-838/2016

Rodriguez-Lloveras X, Bussi G, Francés F, RodriguezCaballero E, Solé-Benet A, Calle M, Benito G (2015) Patterns of runoff and sediment production in response to land-use changes in an ungauged Mediterranean catchment. Journal of Hydrology 531:1054-1066. http://dx.doi.org/10.1016/j.jhydrol.2015.11.014

Sanyal J, Densmore A L, Carbonneau P (2014) Analysing the effect of land-use/cover changes at sub-catchment levels on downstream flood peaks: A semi-distributed modelling approach with sparse data. Catena 118:28-40. DOI: http://dx.doi.org/10.1016/j.catena.2014.01.015 
Savoldi A, Cunha LA (2010) Uma abordagem sobre a agricultura familiar, PRONAF e a modernização da agricultura no Sudoeste do Paraná na década de 1970. Revista Geografar 5(1):25-45.

Scharffernberg WA (2013) Hydrologic Modeling System HEC-HMS, User's Manual, Version 4.0. U.S. Army Corps of Engineers, Hydrologic Engineering Center. Available: http://www.hec.usace.army.mil/software/hec$\mathrm{hms} /$ documentation/HEC HMS_Users_Manual_4.0.pdf. Accessed: Jul 21, 2015.

Silva VPR, Silva MT, Souza EP (2016) Influence of land use change on sediment yield: A case study of the sub-middle of the São Francisco river basin. Engenharia Agrícola 36(6):1005-1015. DOI: http://dx.doi.org/10.1590/1809-4430Eng.Agric.v36n6p1005-1015/2016

Silveira ALL (2005) Desempenho de fórmulas de tempo de concentração em bacias urbanas e rurais. Revista Brasileira de Recursos Hídricos 10(1):5-23. DOI: http://dx.doi.org/10.21168/rbrh.v10n1.p5-29

Suriya S, Mudgal BV (2012) Impact of urbanization on flooding: The thirusoolam sub watershed - A case study. Journal of Hydrology 412-413:210-219. DOI: http://dx.doi.org/10.1016/j.jhydrol.2011.05.008

Tesemma ZK, Wei Y, Peel MC, Western AW (2015) The effect of year-to-year variability of leaf are a index on Variable Infiltration Capacity model performance and simulation of runoff. Advances inWater Resources 83:310322. DOI: http://dx.doi.org/10.1016/j.advwatres.2015.07.002

Tucci CEM, Clarke RT (1997) Impactos das mudanças da cobertura vegetal no escoamento: Revisão. Revista Brasileira de Recursos Hídricos 2(1):135-152.

USDA - United States Departament of Agriculture (1986) Natural Resources Conservation Service. Urban Hydrology for Small Watersheds. In: TR-55. 2 ed. Available: https://www.nrcs.usda.gov/Internet/FSE_DOCUMENTS/stelp rdb1044171.pdf. Accessed: Aug 17, $201 \overline{6}$.
Wang H, Chen Y, Chen Z (2013) Spatial distribution and temporal trends of mean precipitation and extremes in the arid region, northwest of China, during 1960 e 2010. Hydrological Processes 27:1807-1818. DOI: http://dx.doi.org/10.1002/hyp.9339

Welde K, Gebremariam B (2017) Effect of land use land cover dynamics on hydrological response of watershed: Case study of Tekeze Dam watershed, northern Ethiopia. International Soil and Water Conservation Research 5:116. DOI: http://dx.doi.org/10.1016/j.iswcr.2017.03.002

You (2017) Agricultural landscape dynamics in response to economic transition: Comparisons between different spatial planning zones in Ningbo region, China. Land Use Policy 61:316-328. DOI: http://dx.doi.org/10.1016/j.landusepol.2016.11.025

Yu Y, Loiskandl W, Kaul H-P, Himmelbauer M, Wei W, Chen L, Bodner G (2016) Estimation of runoff mitigation by morphologically different cover crop root systems. Journal of Hydrology 538:667-676. DOI: http://dx.doi.org/10.1016/j.jhydrol.2016.04.060

Zhang L, Wang J, Bai Z, Lv C (2015) Effects of vegetation on runoff and soil erosion on reclaimed land in an opencast coal-mine dump in a loess area. Catena 128:44-53. DOI: http://dx.doi.org/10.1016/j.catena.2015.01.016

Zhao X, Huang J, Wu P, Gao H (2014) The dynamic effects of pastures and crop on runoff and sediments reduction at loess slopes under simulated rainfall conditions. Catena 119:1-7. DOI:

http://dx.doi.org/10.1016/j.catena.2014.03.001

Zope PE, Eldho TI, Jothiprakash V (2016) Impacts of land use-land cover change and urbanization on flooding: A case study of Oshiwara river basin in Mumbai, India. Catena 145:142-154. DOI:

http://dx.doi.org/10.1016/j.catena.2016.06.009 